\title{
A Cloud-based Asset Tracking System for Hospitals Using Ultra-wideband Localization
}

\author{
Noushin Karimpour $^{1}$, Zuleyha Akusta Dagdeviren ${ }^{2 *}$, Vahid Khalilpour Akram ${ }^{3}$ and Orhan Dagdeviren ${ }^{4}$ \\ ${ }^{1}$ Ege University, International Computer Institute, Izmir, Turkey (ORCID: 0000-0002-6446-4256), noushin.karimpour@ gmail.com \\ 2* Ege University, International Computer Institute, Izmir, Turkey (ORCID: 0000-0001-9365-326X), zuleyhaakusta@ gmail.com \\ ${ }^{3}$ Ege University, International Computer Institute, Izmir, Turkey (ORCID: 0000-0002-4082-6419), vahid.akram@ege.edu.tr \\ ${ }^{4}$ Ege University, International Computer Institute, Izmir, Turkey (ORCID: 0000-0001-8789-5086), orhan.dagdeviren@ ege.edu.tr
}

(3rd International Congress on Human-Computer Interaction, Optimization and Robotic Applications June 11-13, 2021)

(DOI: $10.31590 /$ ejosat.960454)

\begin{abstract}
ATIF/REFERENCE: Karimpour N. \& Akusta Dagdeviren, Z. \& Khalilpour Akram, V. \& Dagdeviren O. (2021). A Cloud-based Asset Tracking System for Hospitals Using Ultra-wideband Localization. European Journal of Science and Technology, (26), 425430 .
\end{abstract}

\begin{abstract}
Nosocomial infections are fatal diseases caused by microorganisms in the hospital environment. It has mortality rates of up to $70 \%$ in intensive care units. The most important way to fight this infection is to pay attention to the hygiene of the assets in the hospital. Within the scope of this paper, an IoT-based real-time advanced asset tracking system has been implemented. This system consists of three main components: Hand Hygiene Surveillance System, Device Tracking System, and Infection Control System. Providing hand hygiene in hospitals is critical for the prevention of infections. The proposed Hygiene Surveillance System provides hand hygiene control in intensive care units and neonatal services, which are the areas with the highest risk of infections. Received signals from ultrawide-band (UWB) modules are processed by a designed positioning algorithm. While competitors are insufficient in many scenarios because of the 1-2 $\mathrm{m}$ precision positioning, the proposed system provides a solution in these scenarios with $20-25 \mathrm{~cm}$ precision. Antibiotic-resistant nosocomial infection is difficult to treat, contagious, and fatal. These patients are kept in quarantine. During the transportation of these patients, end-to-end hygiene control is required. By using the developed Infection Control System, these patients will be followed end-to-end in real-time. Our system consists 3 main layers. In the first layer, the distributed IoT devices in the environment collect the broadcasted UWB and Bluetooth Low Energy (BLE) signals from the mobile nodes. The strength of the received signals is sent to the second layer which is responsible for calculating the location of mobile nodes based on the received signals from different anchor nodes. The detected locations are sent to the thir layer which provide the real time tracking system for the web and mobile applications. In this layer different technologies such as JSON, Ajax, Server Sent Events, WebSockets, and RestFul technologies are used to deliver the real time location data to the users.
\end{abstract}

Keywords: Internet of things, Cloud computing, Asset tracking, Ultra-wideband, Localization, Medical systems, Hygiene Monitoring.

\section{Hastaneler için Ultra-genişbant Konumlandırma Kullanan Bulut Tabanlı Varlık Takip Sistemi}

$\ddot{O} \mathbf{z}$

Hastane enfeksiyonları, hastane ortamında mikroorganizmaların neden olduğu ölümcül hastalıklardır. Bu enfeksiyonlar, yoğun bakım ünitelerinde \%70'e varan ölüm oranlarına sahiptir. Bu enfeksiyonla savaşmanın en önemli yolu hastanedeki cihazların ve eşyaların hijyenine dikkat etmektir. Bu bildiri kapsamında, IoT tabanlı gerçek zamanlı gelişmiş bir varlık takip sistemi hayata geçirilmiştir. Önerilen bu sistem üç ana bileşenden oluşmaktadır: El Hijyeni Gözetim Sistemi, Cihaz Takip Sistemi ve Enfeksiyon Kontrol Sistemi. Hastanelerde el hijyeninin sağlanması enfeksiyonların önlenmesi açısından kritik öneme sahiptir. Önerilen Hijyen Gözetim Sistemi sayesinde enfeksiyon riskinin en yüksek olduğu alanlar olan yoğun bakım üniteleri ve yenidoğan servislerinde el hijyeni kontrolü

\footnotetext{
*Sorumlu Yazar: zuleyhaakusta@gmail.com
} 
sağlanmaktadır. Ultra geniş bant (UWB) modüllerinden alınan sinyaller, bir konumlandırma algoritması tarafından işlenir ve konum bilgileri üretilir. 1-2 m hassasiyetli konumlandırma nedeniyle birçok senaryoda benzer çalışmalar yetersiz kalırken, UWB teknolojisi sayesinde önerilen sistem bu senaryolarda 20-25 cm hassasiyetle çözüm sunmaktadır. Antibiyotiğe dirençli hastane enfeksiyonunun tedavisi oldukça zordur, bulaşıcıdır ve ölümcüldür. Bu hastalığa yakalananlar mecburi olarak karantinada tutulmaktadır. Bu hastaların nakli sırasında uçtan uca hijyen kontrolü yapılması gerekmektedir. Geliştirilen Enfeksiyon Kontrol Sistemi kullanılarak system tarafindan bu hastalar gerçek zamanlı olarak uçtan uca takip edilecektir. Sistemimiz 3 ana katmandan oluşmaktadır. İlk katmanda, ortamdaki dağıtılmış IoT cihazları, mobil düğümlerden yayınlanan UWB ve Bluetooth Düşük Enerji (BLE) sinyallerini toplar. Alınan sinyallerin gücü, çeşitli kök düğümlerinden alınan sinyallere dayalı olarak mobil düğümlerin konumunun hesaplanmasından sorumlu olan ikinci katmana gönderilir. Tespit edilen lokasyonlar, web ve mobil uygulamalar için gerçek zamanlı takip sistemi sağlayan üçüncü katmana gönderilir. Bu katmanda gerçek zamanlı konum verilerini kullanıcılara ulaştırmak için JSON, Ajax, WebSockets, MongoDB ve RestFul gibi farklı teknolojiler kullanılmaktadır.

Anahtar Kelimeler Nesnelerin İnterneti, Bulut Bilişim, Varlık Takibi, Ultra-genişbant, Konumlandırma, Medikal Sistemler, Hijyen Takibi.

\section{Introduction}

The Internet of Things, which is considered as one of the most promising technologies, has started to be widely used in various fields in the world going through the age of digital transformation (Atrozi et al., 2010), (Tan et al., 2014), (Xu et al., 2014), (Whitmore et al., 2015), (Islam et al., 2015), (Tripathi et al., 2021). The latest developments in new generation wireless communication modules, sensors, memory, and processors have revealed small and powerful hardware that can run programs, can detect events or values, communicate over radio devices and perform local operations. On the other hand, the spread of the Internet and the exponential increase in the variety of small hardware have led to the development of devices that communicate over the Internet and form the Internet of Things (IoT). Like the Internet, IoT has started to become a part of daily life, and people have started to take advantage of IoT technology in transportation (Melis et al., 2016), manufacturing (Mourtis et al., 2016), entertainment (Belka et al., 2019), household chores (He et al., 2019), sports (Wang et al., 2018), and health services (Karimpour et al., 2019). Using such a universal IoT platform, devices can improve the quality of people's daily life by taking on important tasks in industry, agriculture, healthcare, transportation, security, and even homes. An IoT ecosystem consists of web-based smart devices that use embedded processors, sensors, and communications hardware to collect, send, or process the data they receive from their environment. IoT devices share the collected sensor data by connecting to an IoT gateway or other devices where the data is sent to the cloud for processing. These devices may communicate with other related devices and process the received information from each other. Devices do most of the work without the need for human intervention, but people can interact with the devices. The connectivity, networking, and communication protocols used with these web-based devices are highly dependent on the deployed IoT applications.

In recent years, the development of IoT-based tracking systems is the subject of various researches. In various fields, especially in logistics, cargo, industry, health care, and agriculture, asset tracking systems can significantly increase the quality of provided services or produced products. In general, asset tracking and localization systems (Doherty et al., 2001) (Nagpal et al., 2003) (Shang et al., 2003) (Patwari et al., 2005) (Xiao and Ouksel, 2006) (Alhmeidat and Yang, 2007) consist of various devices and software running on these devices. Monitoring of valuable assets against various events such as loss, theft, damage, or tracking instant location information of personnel or patients is critical task in hospitals. For example, reporting the locations visited by healthcare personnel during working hours, the time spent in these locations, and the paths they travel in a hospital environment can be a metric to measure staff productivity. Another important problem in the hospital environment is finding the device sought by the staff. In particular, it is vital to search for critical devices such as EKGs and defibrillators. In addition to the effort and lost time to find these devices, new devices are purchased due to the inefficient use of the devices. Problems such as the locations where the devices are moved during working hours, the time spent in these locations, and the distance between the sought device and the personnel will be solved by path creation services.

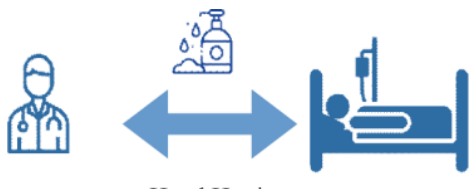

Hand Hygine

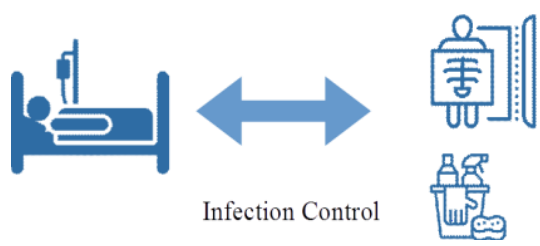

Figure 1. Asset tracking in hospital may reduce the risk of infections.

Compliance monitoring and surveillance is another quite important issue in hospitals because hospital infections have many consequences. Surveillance and measurement of hand hygiene compliance is carried out by employing human observers, and this is considered as a standard. But this process has its difficulties such as human error, loss of observer concentration, or professional deformation. Researchers have used different techniques to deal with these situations such consumption calculation for sanitizing materials or tagging health care workers with electronic devices to follow their locations. Generally tracking the staffs, patients and devices in a hospital can considerably reduce the infections because staff can be notified if they potentially carry a risk of infection (Figure 1). Different companies around the world offer various methods for asset tracking and tracing. For example, the systems offered by AIRcable Gateway, Aruba BLE Tags, BeWhere Asset Tracking, Fathom Asset Tracking, and Kontakt IO companies find the estimated location of assets in homes, offices, and small-scale buildings using BLE. Generally, most of these systems are offered as a product of IoT or telecommunications companies, therefore, the presented systems do not have a special infrastructure. These systems use various algorithms and software techniques to determine the location of target assets. 
The most common methods used in different systems are trilateration, proximity, fingerprinting, Angle of Arrival (AoA), Time of Arrival (ToA), and Time Difference of Arrival (TDoA). In the trilateration method, a node whose position is not known should receive the position information and the distances between from at least 3 anchor nodes that know their positions. All calculations made in this method are based on the measured distance between nodes. Therefore, the slightest error in distance measurements will cause a completely inaccurate position estimation. The accuracy of the results obtained from the trilateration method is often limited, as it is a difficult task to estimate the precise and accurate distance over the signals. The proximity method is a simple method for localization (Khudhair et al., 2016). It analyzes the location of an object with a known position or an area. The proximity method must adjust the number of IoT nodes at known locations. When a tracked target is detected, the target's location is assumed in the proximity range marked by the IoT device. The basic idea of the fingerprinting method is to create a map of Received Signal Strength Indicator (RSSI) values for all possible locations of the target environment (Pei et al., 2017). To create such a map, the target area should be divided into equal cells and the RSSI value of the available signals should be recorded for each cell. After creating the signal map, the input of the positioning system is the RSSI value received by a mobile node that does not know its location, and the output of the system is the location information of a record that matches the value given as input in the database. The AoA method uses a set of special antennas to estimate the angle of received signals (Peng and Sichitiu, 2006). The receiving node determines the position of the signal source after calculating the angle of the surrounding signals with a set of antennas that can calculate the angle of the received signal. Then, the position of the node is calculated using the output and arrival time difference of the signal and the distance between the antennas. The ToA or ToF method uses the propagation time of the signal to estimate the distance between the receiver and the sender (Aditya et al., 2018). Considering the relationship $d=v \times$ $t$ between distance $(d)$, velocity $(v)$ and time $(t)$, if the receiver calculates the propagation time of the signal, it can find the distance to the sender because the propagation speed of the signal is always equal to the speed of light. TDoA is a method that uses the time difference of the sent and received signals instead of the transmission time (McClelland et al., 2017). In the TDoA method, the sender does not add any timestamps to the message and only the receiving time is recorded by the receivers. This method requires at least two receivers. After receiving the signal from both receiving nodes, the difference in arrival time at both nodes is calculated. Afterward, the distance difference between the sender and receivers is calculated from the equation $\Delta d=v \times \Delta t$.

In this paper, we propose a hygiene surveillance, device tracking, and infection control system. BLE is the most common technology that is used in the most well-known products in the world. Since BLE has 1-2 m sensitivity, it is not technically possible to operate with the desired sensitivity in many scenarios. For example, an antiseptic location may not be stable and could be in various positions in the room, or even placed on the foot or bedside of the patient's bed. In this case, precise positioning is critical to detect the clean and dirty materials or persons. To solve this problem, Ultra-Wide Band (UWB) technology can be used in the hand hygiene surveillance systems. In this way, a much more sensitive and innovative hygiene monitoring system can be designed that can work e-ISSN: 2148-2683 especially in intensive care units. Current device tracking systems use BLE and WiFi technologies. These technologies have various problems in many scenarios. For example, it is a natural situation that the devices are closer than $1 \mathrm{~m}$ to each other, which is frequently encountered in hospitals. There are mobile devices such as ultrasound, defibrillator, and EKG in the hospital which finding their real time location is one of the important problems in hospitals. Staff usually take effort to search for these devices and usually finding these devices is critical for patients. Using an unhygienic device is very risky in terms of infection. An effective and innovative device tracking system may track the both location and device hygiene information. Controlling patients with nosocomial infections is a very important problem in order to avoid transmit the disease to both healthcare workers and other patients. Especially when the patient is transported from his/her room to a clinic, the clinical staff should make preliminary preparations, monitor and clean the path through which the patient passes in real-time, and clean the clinics after clinic visits. Our proposed system is aimed to achieve this mentioned issue. The remaining parts of this paper have been organized as follow; Section 2 provides the general architecture and the details of the proposed system. Section 3 discuss about the results and provides a comparison between the available commercial systems. Finally, Section 4 draws the conclusion and discuss about the future works.

\section{Material and Method}

The proposed system for asset tracking and hand hygiene in hospitals consist of 3 main layers which are the signal collection layer, the positioning layer, and the analysis and reporting layer.

\subsection{Signal Collection Layer}

The proposed system uses UWB (Ultra Wideband) and BLE (Bluetooth Low Energy) technologies to find the position of assets. UWB is a short-range and high-speed wireless communication technology with a bandwidth of $7.5 \mathrm{GHz}(3.1$ $\mathrm{GHz}$ to $10.6 \mathrm{GHz}$ ). UWB devices operate using a very wide transmission band and a very short electrical pulse (in the order of nanoseconds or picoseconds). In UWB technology, the minimum distance between the sender and receiver can be measured more easily and more precisely. The UWB-based systems, find the distance between the target assets using the Time of Arrival method. Beside the UWB technology, the proposed system can benefit from BLE to estimate the location mobile assets. BLE consumes less energy because the frequency of BLE signals is low. Using the BLE signal, the formula RSSI= $\mathrm{A}-10 . n \cdot \log (d)$ can be used to find the distance between a target asset and the BLE anchor device. In this formula, $n$ is the power loss ratio of the signal (between 1 and 2), $A$ is the RSSI value received at $1 \mathrm{~m}$, and $d$ is the distance between the sender and the receiver. To use the BLE and UWB signals, various anchor nodes should be placed in the hospital environments. These devices may receive the wireless signals which are periodically broadcasted by the mobile devices. The received signals and the id of the sender is sent to the Positioning Layer which is responsible for finding the location of the mobile asset. Based on the mobile device technology both BLE and UWB anchors may collect the signals from the environment and send them to the positioning layer.

\subsection{Positioning Layer}




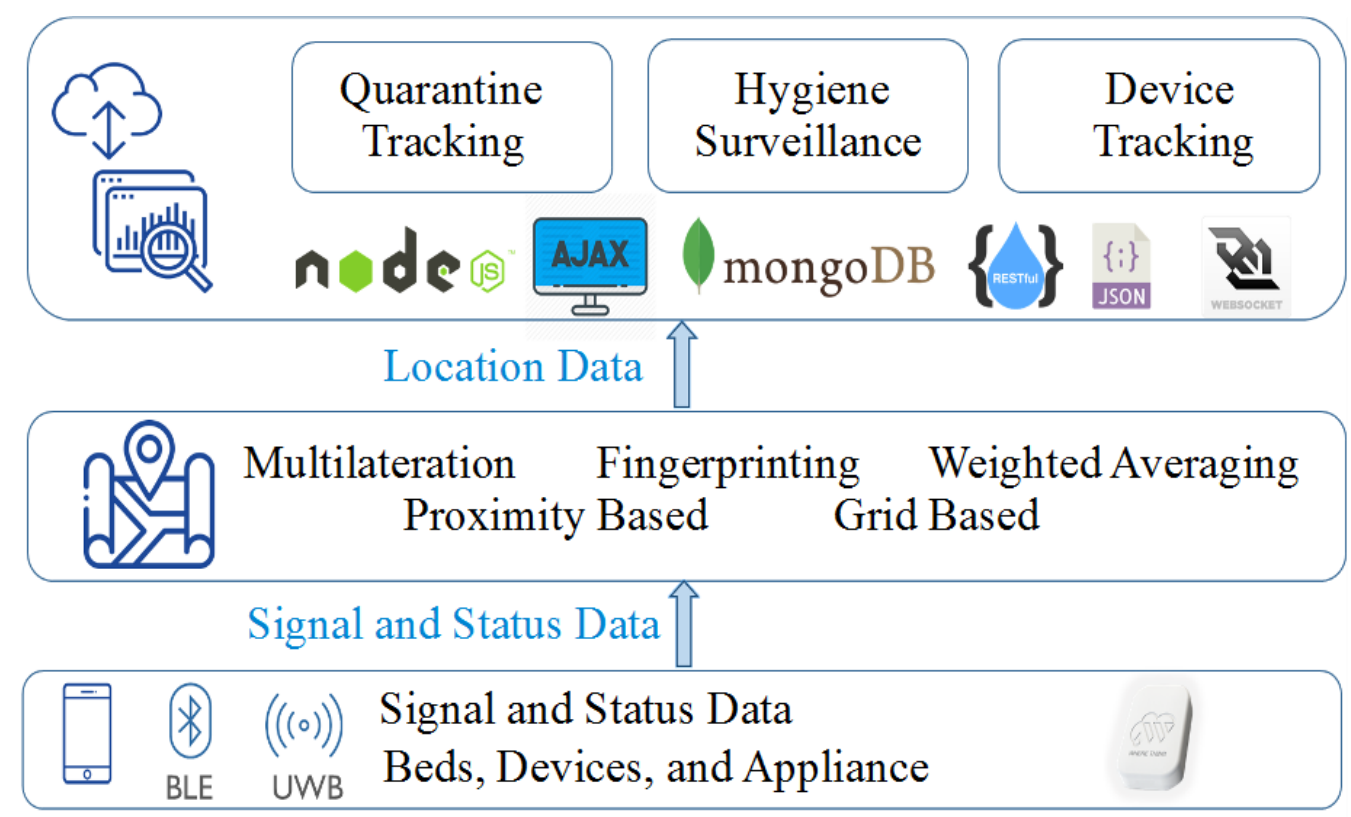

While BLE is used in applications where we need to that require $\mathrm{cm}$-based precision. For tracking target assets, small monitor with meter-wide precision, UWB is used in the cases

Figure 2. The general architecture of the proposed asset tracking system

devices which periodically send BLE or UWB signals are attached to them. The anchor devices in the environment measure the strength of received signals and send this information to the positioning layer. In the positioning layer, the distance between the target entity and the anchors measured based on the strength of the received signals. The distance information is sent to a different positioning algorithm running on the server. The system administrator may select one of the standard localization algorithms such as multilateration, fingerprinting, weighted averaging or proximity based method. The result of the positioning algorithm is presented to the users of the system via web services. UWB-based positioning systems determine the distance between target entities and beacons more precisely based on the arrival time of the signals. Adaptive version of multilateration, weighted averaging, proximity, and fingerprinting techniques can be used to determine the location of mobile devices using UWB signals. The location of personnel or patients may be determined using the broadcasted BLE signals from their mobile phones.

\subsection{Real Time Analysis and Reporting Layer}

The received location information from the tracking devices are stored in a server which is running on the cloud. The information coming to the cloud server is sent to the Web or Mobile applications via the web services. The tracking and the cloud system can be used in common for different applications. For custom requirements a special web or mobile application can be developed to meet the system conditions. For example, the floor plans of the hospital can be entered into web or mobile application to track the patients and devices. In this way, the locations of the assets will be shown on the user interface. For developing the web applications different technologies and language such JavaScript, JSON, Ajax, Server-Sent Events, Web Sockets, and RestFul services can be used. Anonymous reports (without covering the patients or staff data) can be generated to track end evaluate the hygiene procedures.
The general architecture of the proposed asset tracking system is shown in Figure 2. At the lowest layer, we use BLE and UWB modules at the hardware level. We place anchors in the different locations that need to be monitored in the hospital. The collected signal data from the anchor nodes are the input of the positioning layer. In the positioning layer, a selected algorithm by the administrator finds the location information by using multilateration, fingerprinting, weighted averaging and, proximity based techniques. At the top layer, we have a detailed reporting modules running in the cloud server. These modules used up-to-date technologies such as NodeJs, Ajax, and, MongoDB.

\section{Results and Discussion}

In the pilot implementation, we placed ESP32 devices as anchors in the 3 locations of hospital to track the mobile nodes. We used the mobile phones to broadcast BLE signals. These signals are collected by the ESP devices and the collected signal strength data and the collected information are sent to a serve over WiFi connection and Internet. After determining the location of the mobile node in the positioning layer the real time location of the mobile nodes is shown to the user on the map. An example screenshot of the system is given in Figure 3.

Table 1 shows the comparison between competitor companies and proposed system. This comparison has been reviewed in two main metrics as supported systems and technologies. Infection Control System, Device Tracking System, and Hygiene Surveillance System are discussed under the supported systems metric. The proposed system covers all metrics while the other systems only support some of these tasks. Although Stanley, Ubisense, Comport, Impinj, Intelligent InSites, Aruba, Midmark, Sanitag, and Versus work in the health field (Ruiz and Granja, 2017) they do not provide any of the services we recommend, so they are not included in the comparison table. CenTrak and Zebra were chosen because they are well known in the field of indoor localization and already completed large-scale projects. CenTrak, one of the important companies developing hospital asset tracking systems in the 


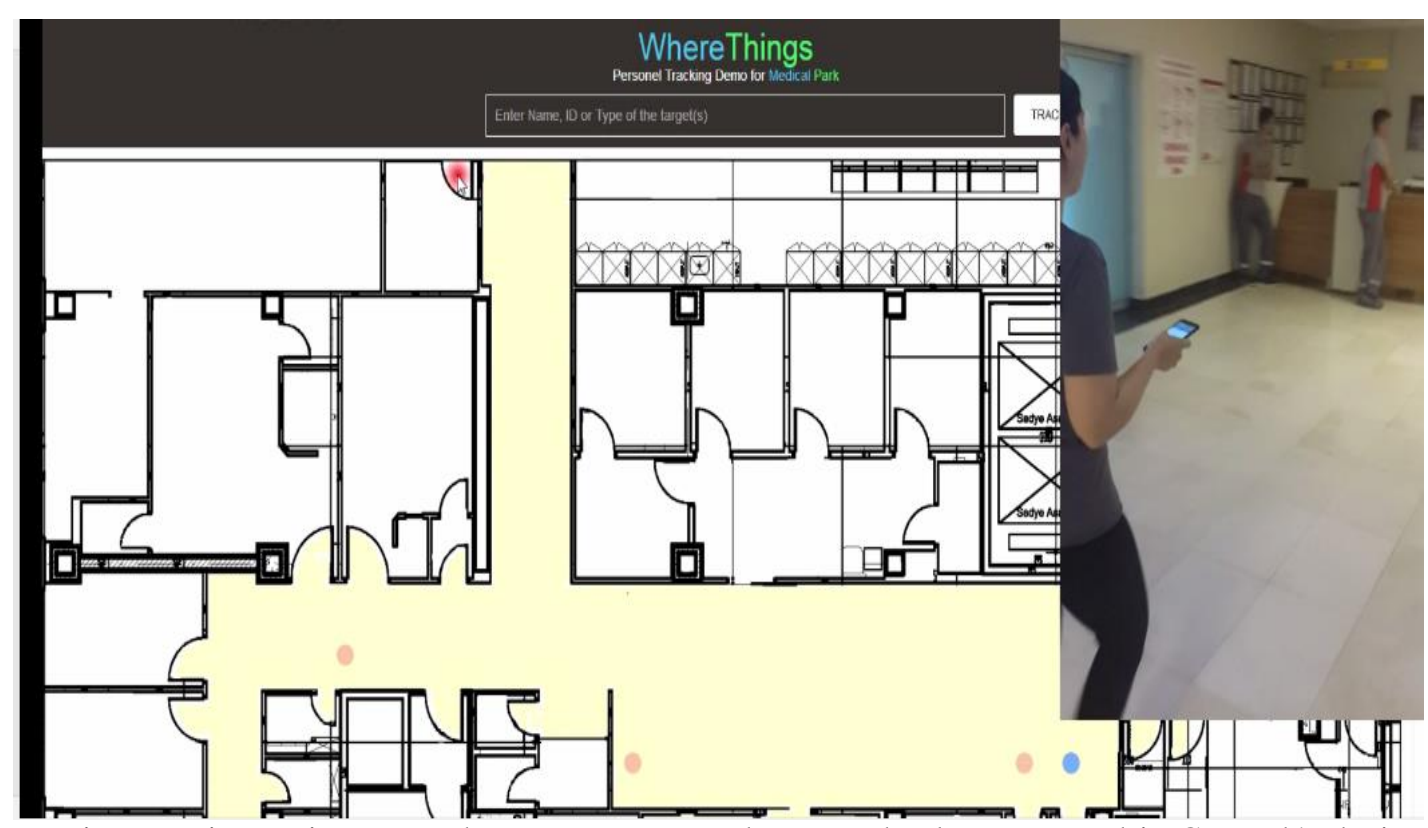

global market, offers various services to its users. These systems use BLE-based localization technology. CenTrak has no reported activity on the infection control system. In addition, since WiFi

and BLE technology are used in CenTrak's device tracking and hygiene surveillance system, the sensitivity of their system is

Figure 3. Pilot implementation of the proposed system.

Table 1. Comparison of the tracking systems in hospital

\begin{tabular}{|c|c|c|c|}
\hline & \multicolumn{3}{|c|}{ SUPPORTED SYSTEMS } \\
\hline Proposed System & $\begin{array}{c}\text { Infection Control } \\
\text { System } \\
\text { infection control }\end{array}$ & $\begin{array}{c}\text { Device Tracking System } \\
\text { with BLE-based system }\end{array}$ & $\begin{array}{c}\text { Made with a UWB-based system } \\
\text { in centimeters }(20-30 \mathrm{~cm}) \\
\text { diameter }\end{array}$ \\
\hline CenTrak & Not Supported & $\begin{array}{c}\text { Only location tracking with } \\
\text { the WiFi-based system }\end{array}$ & $\begin{array}{c}\text { Made with a BLE-based system } \\
\text { in meters }(1-2 \text { m) } \\
\text { diameter }\end{array}$ \\
\hline Zebra & Not Supported & $\begin{array}{c}\text { Only location tracking with } \\
\text { the WiFi-based system }\end{array}$ & Not Supported \\
\hline Teletracking & Not Supported & Not Supported & $\begin{array}{c}\text { Made with a WiFi-based system } \\
\text { in meters (1-3 m) diameter }\end{array}$ \\
\hline
\end{tabular}

much lower than the proposed UWB-based system. In the developed systems by Zebra, there are no infection control and hygiene surveillance modules. Since the device tracking system is made with WiFi technology, the location of the devices is

estimated with considerable error ratio. Also the energy consumption of $\mathrm{WiFi}$ based systems is high. Although Teletracking offers a WiFi-based system for detecting hand hygiene, it does not offer any service for infection and device control.

\section{Conclusions}

In this paper we proposed a cloud-based IoT asset tracking system for hospitals using ultra-wideband and BLE localization. The proposed system has 3 main layers. In the lowest layer, the distributed IoT devices in the hospital, collect the broadcasted BLE and UWB signals from the mobile nodes. The strength of received signals is measured by the IoT devices and these data are sent to the second layer which is responsible for finding the location of mobile nodes. In this layer different algorithms, such as multilateration, weighted averaging, finger printing and approximated methods can be used to find the location of mobile nodes. The third layer shows the detected positions on the web pages or mobile applications. The data are sent over HTTP protocol the mobile or web client. Also different analytical report can be generated by the reporting tool. As the future work, we plan to implement the proposed system as a full functioning software, design more efficient localization algorithms and develop custom anchors using new generation of IoT devices.

\section{References}

Alhmiedat,T. A. and Yang, S. H. (2007) A survey: Localization and tracking mobile targets through wireless sensors network. PGNet.

Atzori, L., Iera, A. \& Morabito, G. (2010). The Internet of Things: A survey, Elsevier, Computer Networks, Volume 54, Issue 15. 
Belka, R. (2019, November). An indoor tracking system and pattern recognition algorithms as key components of IoTbased entertainment industry. In Photonics Applications in Astronomy, Communications, Industry, and High-Energy Physics Experiments 2019 (Vol. 11176, p. 111765P). International Society for Optics and Photonics.

Doherty, L., Pister, K. S. J., and Ghaoui, L. E. (2001) Convex position estimation in wireless sensor networks. Proc. of the 12th Annual Joint Conf. of the IEEE Computer and Communications Societies, Anchorage, Alaska, 22-26 April, pp. 1655-1663. IEEE Computer Society, Washington.

He, Y., Bahirat, P., Knijnenburg, B. P., \& Menon, A. (2019). A data-driven approach to designing for privacy in household IoT. ACM Transactions on Interactive Intelligent Systems (TiiS), 10(1), 1-47.

Karimpour, N., Karaduman, B., Ural, A., Challenger, M., \& Dagdeviren, O. (2019, June). Iot based hand hygiene compliance monitoring. In 2019 International Symposium on Networks, Computers and Communications (ISNCC) (pp. 1-6). IEEE.

Khudhair, A. A., Jabbar, S. Q., Sulttan, M. Q., \& Wang, D. (2016). Wireless indoor localization systems and techniques: survey and comparative study. Indonesian Journal of Electrical Engineering and Computer Science, 3(2), 392409.

Islam, S. M. R., Kwak, D.,Kabir, M. H., Hossain M. and Kwak, K. (2015). The Internet of Things for Health Care: A Comprehensive Survey, in IEEE Access, vol. 3, pp. 678-708.

McClelland, K., Flinner, H., Abler, R., Garver, P., \& George, J. (2017, September). Time Difference of Arrival Localization Testbed: Development, Calibration, and Automation. In Proceedings of the GNU Radio Conference (Vol. 2, No. 1, pp. 8-8).

Melis, A., Prandini, M., Sartori, L., \& Callegati, F. (2016, September). Public transportation, IoT, trust and urban habits. In International conference on internet science (pp. 318-325). Springer, Cham.

Mourtzis, D., Vlachou, E., \& Milas, N. J. P. C. (2016). Industrial big data as a result of IoT adoption in manufacturing. Procedia cirp, 55, 290-295.

Nagpal, R., Shrobe, H., and Bachrach, J. (2003) Organizing a global coordinate system from local information on an ad hoc sensor network. Proc. of the 2nd Int. Workshop on Information Processing in Sensor Networks, Palo Alto, CA, USA, 22-23 April, pp. 333-348. Springer-Verlag, Berlin.

Patwari, N., Ash, J. N., Kyperountas, S., Hero, A. O., Moses, R. L., and Correal, N. S. (2005) Locating the nodes: Cooperative localization in wireless sensor networks. IEEE Signal Processing Magazine, 22(4), 54-69.

Pei, L., Liu, J., Chen, Y., Chen, R., \& Chen, L. (2017). Evaluation of fingerprinting-based $\mathrm{WiFi}$ indoor localization coexisted with Bluetooth. The Journal of Global Positioning Systems, 15(1), 1-12.

Peng, R., \& Sichitiu, M. L. (2006, September). Angle of arrival localization for wireless sensor networks. In 2006 3rd annual IEEE communications society on sensor and ad hoc communications and networks (Vol. 1, pp. 374-382). IEEE.

Ruiz, A. R. J., \& Granja, F. S. (2017). Comparing ubisense, bespoon, and decawave uwb location systems: Indoor performance analysis. IEEE Transactions on instrumentation and Measurement, 66(8), 2106-2117.

Shang, Y., Fromherz, M. P. J., Ruml, W., and Zhang, Y. (2003) Localization from mere connectivity. Proc. of the 4th ACM
Int. Symp. on Mobile Ad Hoc Networking and Computing, Annapolis, Maryland, USA, 1-3 June, pp. 201-212. ACM Press, New York.

Tan J. \& Koo, S. G. M. (2014). A Survey of Technologies in Internet of Things, 2014 IEEE International Conference on Distributed Computing in Sensor Systems, 2014, pp. 269274.

Tripathi, A. K., Sharma, K., Bala, M., Kumar, A., Menon, V. G. and Bashir, A. K. (2021) A Parallel Military-Dog-Based Algorithm for Clustering Big Data in Cognitive Industrial Internet of Things, IEEE Transactions on Industrial Informatics, vol. 17, no. 3, pp. 2134-2142.

Wang, Y., Chen, M., Wang, X., Chan, R. H., \& Li, W. J. (2018). IoT for next-generation racket sports training. IEEE Internet of Things Journal, 5(6), 4558-4566.

Whitmore, A., Agarwal, A. \& Da Xu, L. (2015). The Internet of Things-A survey of topics and trends. Inf Syst Front 17, 261-274.

Xiao, L. and Ouksel, A. M. (2006) Scalable self-configuring integration of localization and indexing in wireless ad-hoc sensor networks. Proc. of the 7th Int. Conf. on Mobile Data Management, Nara, Japan, 9-13 May. IEEE, Washington.

$\mathrm{Xu}, \mathrm{L}$. D., He, W. and Li, S. (2014). Internet of Things in Industries: A Survey, in IEEE Transactions on Industrial Informatics, vol. 10, no. 4, pp. 2233-2243. 